\title{
Mongolia In An Emerging Northeast Asian Region
}

\author{
Julian DIERKES ${ }^{1 *}$ \\ MENDEE Jargalsaikhan ${ }^{2}$
}

${ }^{1}$ - A sociologist at the University of British Columbia where he is an associate professor in the School of Public Policy and Global Affairs.

2 - A Political Science PhD candidate at the University of British Columbia. mendee@alumni.ubc.ca

The regional integration of Northeast Asia is far behind other regions. Recent developments on the Korean Peninsula offer the possibility of a trajectory toward integration. Any regionalization would be in Mongolia's national interest. Mongolia's material contribution to regional integration would be limited. However, Mongolia could contribute greatly to the regionalization processes We highlight such process contributions: (1) the provision of neutral ground for dialogue between conflicting parties; (2) hosting peacekeeping and disaster-relief exercises; (3) promoting non-governmental connections; and (4) serving as an example for political and economic transition. If US-DPRK negotiations result in positive steps, Mongolia could contribute expertise in the establishment of a nuclear-weapon free zone.

Keywords: Mongolia, foreign policy, Northeast Asia, North Korea, regionalization

\section{Introduction}

uddenly, in Spring 2018, the world is revolving around Northeast Asia, and the region may be in flux. The single dynamic element in this development is shifts in the relationship between the Democratic People's Republic of Korea (DPRK - North Korea) and the world for the first time since

* Corresponding author: Julian.Dierkes@ubc.ca

This article is published under the Creative Commons CC-BY-ND License (http://creativecommons.org/licenses/by-nd/4.0/). This license permits use, distribution and reproduction, commercial and non-commercial, provided that the original work is properly cited and is not changed anyway. 
the North Korean last charm offensive in 2000. ${ }^{1}$ From the belligerence of 2017, especially in the direct stand-off between US President Donald Trump and Chairman of the Workers' Party of Korea Kim Jong-un, to repeated visits by Kim to China, but also meetings with Republic of Korea President Moon Jae-in and Trump, we find ourselves in a moment of confused and guarded optimism that positive developments on the Korean peninsula may be on the horizon. More of these developments will occur by the time this issue is published, and the Korean situation is not the subject of this article. However, developments in Korea may pave the way for the emergence of a Northeast Region and that is highly relevant to Mongolian foreign policy, which arrives at the crossroads of merging into Chinese and/or Russian regionalization efforts or deepening its integration with Northeast Asia.

\section{Where is Northeast Asia heading?}

We base our discussion on an optimistic scenario of constructive engagement with North Korea and a related impetus for tentative regional integration. Clearly, there are two other, possibly more likely, scenarios. The most probable appears to be some kind of collapse or stall of current efforts and a return to the status quo ante, that is to the standoff of 2017. Another scenario that is hopefully remote is some kind of deterioration that leads to actual hostilities. Both scenarios would have an impact on Mongolia, but Mongolian foreign policy has little impact on these possible developments. However, continued tensions in Northeast Asia would make it more difficult for Mongolia to withstand pressures from Beijing to join in the Shanghai Cooperation Organization (SCO) and from the Kremlin to join the Eurasian Economic Union (EEU).

What exactly a scenario of constructive engagement might bring is also very unclear. Obviously, there are questions around de-nuclearization, but also economic relations, sanctions, and any kind of opening of North Korea to the world and the region, including possible migration flows. For our purpose here, suffice it to assume that any kind of constructive engagement would enable discussions of regional integration, at least in a limited fashion.

If some such positive scenario in interactions with the DPRK comes to pass, what does this imply for Mongolia? Does Mongolia have an international relations interest in the emergence of a Northeast Asian region? What contributions might Mongolia make to bring about a regional integration process, and what contributions could Mongolia make to that region?

See Samuel Kim, "North Korea in 2000: Surviving through High Hopes of Summit Diplomacy," Asian Survey, 2001 (41:1), 12-29. 


\section{Northeast Asia}

The world has seen several projects of regional integration since the end of World War II. The foremost example is the European Union, of course. As far as regional integration is concerned the EU has clearly achieved the highest degree, despite perennial struggles and current challenges.

But, other regions have followed the EU example or have embraced regional integration projects of their own. From ASEAN in Asia, to MERCOSUR in South America and the common currencies of African confederations. Most regions, including the EU, have started these processes through the creation of common customs areas and have later added other measures of economic integration, the liberalization of mobility (goods, capital, people) within the region, to some common political institutions or even military alignment.

None of these elements of regional integration exist in Northeast Asia and the countries one might include in a Northeast Asian region are not themselves involved in other regional groupings.

The most obvious geographical grouping of Northeast Asian countries would be one that includes China, Japan, the Koreas and Mongolia. In any such grouping, one of the challenges is how to include the Russian Far East, as it is clearly a potentially important participant in regional activities, yet it participates only as a region of a larger country. While that is also true of China, China's orientation toward Northeast Asia has historically been much stronger than Russia's orientation towards its Pacific region. Any listing also begs the question of which China should be included, i.e. whether this would include Hong Kong and Taiwan, for example. While the pretense of treating Hong Kong separately is disappearing, regional integration involving the People's Republic of China and Taiwan would seem impossible, and Taiwan is generally oriented in different directions in its foreign policy. In the scenario under consideration here, the Northeast Asian region would thus consist of China, Japan, the DPRK, the Republic of Korea, and Mongolia.

Northeast Asia has none of the elements of regional integration we see elsewhere. The only concrete and tangible links in the region are the Free Trade Agreements (FTAs) between China and South Korea (2015) and Japan and Mongolia,the latter came into effect in 2017. There are other bilateral and trilateral FTAs under negotiation (CHN-JPN-KOR, for example), but none of these look likely to be concluded any time soon. There are very few hard or soft infrastructure links between Northeast Asian countries, even if we excluded the DPRK from consideration for the moment because of sanctions and other 
factors. It is surprisingly cumbersome to travel between Northeast Asian cities, even when distances are not so great, as they are not between the four capitals of Beijing, Seoul, Tokyo and Ulaanbaatar. Neither the casual tourist nor professionals like businesspeople or policymakers would ever feel like they are circulating within a defined region in this context, even though visa-free travel for some passports has improved this situation somewhat.

Numerous projects, which could boost regional economic cooperation, have been stalled. The Greater Tumen River Initiative (GTI), for instance, was created in 1990 and financed by the UNDP to promote economic cooperation in five priority sectors (transport, tourism, energy, investment and environment) among China, Mongolia, North Korea, South Korea, and Russia. However, the project lost its momentum from 1998 despite many feasibility studies and project proposals. ${ }^{2}$ Instead, the Tumen River area has become one of the corridors for North Korean refugees to run into China, Russia, and Mongolia. ${ }^{3}$ Other notable projects have been the railways and pipelines connecting Russian Siberia and Far East with South Korea through North Korea. The upgrade of the Rajan-Khasan Railway (between Russia and North Korea) and the construction of the inter-Korean railway have been an on and off topic among all three countries. As relations improved, the two Koreas did the first test run for the railway and Russians upgraded the railway. However, all activities are suspended as the mood of Pyongyang and Washington changes.

\section{Mongolia's Interests in a Northeast Asian Region based on its Foreign Policy}

Mongolia's interests in the Northeast Asian region are long-standing and historic, but often constrained by its 'regionless' fate, geopolitical interests, actions of the Kremlin, and fear of Chinese economic and demographic expansion.

Because of its geographic location, Mongolia is physically isolated from several regional blocs - for example, Central Asia, and Eurasia. For all these regional blocs other than Northeast Asia, the inclusion of Mongolia is not obvious due to underdeveloped political, economic and social links. At the same time, Mongolia provides limited geostrategic and economic attractions for these regions. Therefore, the 'regionless' fate is the foremost challenge for

See, for example, Jean-Marc F. Blanchard, "The Heyday of Beijing's Participation in the Tumen River Area Development Programme, 1990-95: A Political Explanation”, Journal of Contemporary China, 2000 (9:24), pp. 271-290.

3 See, for example, Andrei Lankov, "North Korean Refugees in Northeast China", Asian Survey, 2004 (44: 6), pp. 856-873. 
Mongolia's integration to all possible regional blocs. From three regional blocs, Northeast Asia is the most proximate and rational choice for Mongolia. But, there are two major challenges - the Kremlin's geopolitics and Mongolia's fear of China.

Since the 1920s, Mongolia has been a geopolitical buffer state for Russia to maintain its strategic advantage over China. As Sino-Russian relations improve, the Kremlin relinquished its control and influence in Mongolia, but it would hardly allow Mongolia to fall into the Chinese sphere of influence. Inheriting a Soviet legacy, the Kremlin is still able to maintain its influence over infrastructure development (e.g., railroads, electric grids), strategic mining deposits such as uranium, and the petroleum supply. ${ }^{4}$ Even though Mongolia gained full sovereignty from the Kremlin in the 1990s, Russia has blocked numerous economic projects, which would attract investments from Northeast Asian economies and increase Mongolia's exports to the region.

The other major obstacle for Mongolia's outreach to Northeast Asia is a lingering fear of China. Discourses of Chinese takeover, economic control, and demographic expansion have played a prominent role in domestic politics, especially, electoral politics. But, Mongolia's economic integration to Northeast Asian economies is possible only through Chinese markets and infrastructure. In the absence of the Russian economic assistance, Chinese investment, loans, and labor are only available option to build such infrastructure. However, the fear of China is alive and plays its role in hindering the Mongolia's regional integration.

In spite of these three major challenges, Mongolia has been successful in developing bilateral relations with all Northeast Asian nations beyond its southern neighbour, China, and traditional ally, North Korea. Japan became Mongolia's first strategic as well as free-trade partner from its newly found 'third neighbours' whereas Mongolia's economic and cultural ties with South Korea have reached new momentum. Without crossing Beijing's red lines on Taiwan and Hong Kong, Mongolia already established modest economic and cultural exchanges. However, none of Northeast Asian states have any sort of dependency on Mongolia; therefore, Mongolia's outreach to these countries is mostly one-sided.

In addition to the stated foreign policy aims of maintaining constructive relations with its immediate neighbours, building ties with 'third neighbours', and actively participating in multilateral activities, a fourth aim has quietly

See Sharad K. Soni, "Russian Policy towards Northeast Asia: The Mongolia Factor", The Mongolian Journal of International Affairs, vol. 19, 2014, pp. 34-48. Also, see Sergey Radchenko, "Sino-Russian Competition in Mongolia," in Gilbert Rozman and Sergey Radchenko, International Relations and Asia's Northern Tier (Singapore: Palgrave Macmillan, 2018), pp. 111-125. 
become a major focus of Mongolia's foreign policy over the past several years, economic diplomacy and regional trade. ${ }^{5}$ This shift has come as Mongolia's economy has been formally integrated into a global economy through the 1997 accession to the WTO. While trade was limited initially, the emergence of Mongolia as a resource economy has pegged the fate of its economic development more closely to the Chinese economy, but also to trade more broadly.

The friendly relations built through third neighbour links have thus blossomed into a regional economic focus for relations with Asian countries like Australia, India, but also countries in Northeast Asia. From a foreign policy that is ultimately aimed at securing Mongolia's sovereignty and thus political future, current diplomacy includes many more economic interests. Here, an emerging Northeast Asian region offers many possibilities for Mongolia.

First, economic integration in the region would offer Mongolia some measure of counteracting its landlockedness. While no direct sea access would be gained, an integrated Northeast Asian economy would allow Mongolia to diversify beyond China as its shipping route, even when transit through China would still be required on some routes to North Korean harbours. But overall greater activity in the region would also reinvigorate the Russian Far East thus potentially enabling more shipping for Mongolia.

As far as Chinese infrastructure is concerned, any semblance of a regional dynamic would like prompt the Chinese government to incorporate the region into the Belt and Road Initiative and make Northeast Asia an additional spoke in China's trade system. Such infrastructure would likely benefit Mongolia's trade position.

If Mongolia were to become a relatively junior partner in a Northeast Asian region, it would also avoid a regional grouping that is dominated by China or Russia, like the SCO or EEU.

An economically developing North Korea would likely be focused very closely on China, but Mongolia has some lessons to offer in its experience with transitioning an economy, particularly when it comes to natural resources which are likely a strong element in any North Korean economic reform. Here, opportunities for investment, joint ventures, and the sharing of Mongolian expertise, offer a concrete area of interest in regional integration.

Finally, there are much more speculative scenarios where regional integration would enable Mongolian diversification into areas that might emerge as precious commodities in the future, fresh air, cold, and sunshine.

Julian Dierkes, "Mongolia in the Region: Time for Economic Foreign Policy," 23 March 2014, http://www.eastasiaforum.org/2014/03/23/mongolia-in-the-region-time-for-economic-foreignpolicy/ (Accessed 16 July 2018). 
Initiatives such as Gobitec that envision Mongolia as an alternative energy (primarily solar) exporter to China, Japan and Korea are dependent on advances in transmission technology and the domestic electricity grid in Mongolia, but they are also dependent on a regional transmission infrastructure. That infrastructure would seem much more plausible if it involved North Korea and some regionalization. While such regionalization may seem far off, its potential economic benefits are large for Mongolia and thus constitute another interests in regionalization.

Beyond solar power there are also scenarios that see Mongolia emerging as a clean air or cold giant in a world that faces challenges rooted in climate change and its consequences.

While Mongolia's foreign policy has thus only begun to incorporate economic relations, national economic interests very much point to the Northeast Asian region.

\section{Mongolia's Potential Contributions to the Construction of a Northeast Region}

Mongolia's potential concrete contributions to the construction of a Northeast Asian region are limited, but could be meaningful - but only if other countries support such efforts. On the other hand, Mongolia does have potentially significant contributions to make to the process of regionalization.

One area for such contribution is the provision of neutral ground for dialogue between conflicting parties. Capitalizing on its friendly relations with all countries in the region and the absence of vested interests, Mongolia could easily facilitate dialogue among conflicting states. For example, along with China, Vietnam, and Malaysia, Mongolia facilitated a series of dialogues between the conflicting parties such as Japan - North Korea and the United States - North Korea. Since 2014, Mongolia has hosted five rounds of a track 1.5 dialogue, known as the UB Dialogue, involving all states from Northeast Asia. ${ }^{6}$ This dialogue could serve as a brainstorming venue for exploring potential themes - such as denuclearization and extension of the nuclear weapon free zone, establishment of the regional stand-by forces for peacekeeping and disaster-relief, and the creation of a security dialogue mechanism.

Another area is peacekeeping and disaster-relief exercise. From 2003, with extensive assistance from the United States Defence Department, Mongolia established the Five Hills Peacekeeping Training Centre, which now hosts military personnels from China, Japan, South Korea, and United States for an

See Mendee Jargalsaikhan, "The UB Dialogue at the Crossroads", 12 June 2018, http://blogs. ubc.ca/mongolia/2018/ub-dialogue-2018/ (Accessed 12 July 2018). 
annual peacekeeping exercise, Khaan Quest. ${ }^{7}$ This is the only command post and field training exercise for regional militaries practice under the spirit of the United Nations' peacekeeping operations. At the same time, Mongolia began to develop similar multilateral venues for disaster-relief and humanitarian assistance. The Gobi Wolf exercise, which began in 2009, now aims to promote itself as a regional exercise. In 2018, Mongolia hosted the Asian Ministerial Conference on Disaster Risk Reduction, which was attended by all countries of Northeast Asia. ${ }^{8}$

Another area could include leadership in various types of venues promoting non-governmental connections. With the support of the Asia Foundation, Mongolia has hosted three rounds of the Northeast Asian Mayor's Forum, which was attended by 18 city mayors from all six Northeast Asian states. ${ }^{9}$ At the same time, Mongolia also encourages sporting, women, and youth events. The major challenge for Mongolia making a real contribution will depend on interests and financial support from participating countries. In order to share financial burdens, Mongolia can specialize on areas - such as nuclear weapon free zones, peacekeeping, and disaster-relief - to provide different venues for senior leadership meeting, academic fora, staff-planning exercises, as well as capstone events (e.g., Khaan Quest - peacekeeping; Gobi Wolf - disaster-relief) for improving the interoperability and experience-sharing venues.

Beyond this potentially concrete and material contributions, Mongolia could play a significant role in a regionalization process because of its unique position vis-a-vis other participants in such a process.

In the region, any hostilities with potential regional partners occurred far back in history. Most recently, that would be the defeat of a Japanese invasion by Mongolian and Soviet forces at the battle of Khalkhyn Gol in 1939. ${ }^{10}$ This defeat makes Mongolia unique as an East Asian nation that was not subject to Japanese colonialism. Even further back, prior to its 1911 independence, Mongolia was colonized by the Qing dynasty. While the memory of that historical relationship was kept alive by socialist-era propaganda, it relates to a historical context that has been overcome through several regime changes on both sides.

See, for example, "Khaan Quest 2014: a Small Exercise with Big Implications", 19 June 2014 https://www.csis.org/analysis/pacnet-45-khaan-quest-2014-small-exercise-big-implications (Accessed 15 July 2018)

8 “2018 Asian Ministerial Conference on Disaster Risk Reduction”, 3-6 July 2018, https://www. unisdr.org/conference/2018/amcdrr (Accessed 12 July 2018).

9 MONTSAME, "Mayors of Northeast Asian Countries Exchanging Experiences", 19 June 2018, http://montsame.mn/en/read/15634 (Accessed 16 July 2018).

10 Alvin D. Coox, Nomonhan: Japan against Russia, 1939 (Stanford, Calif.: Stanford University Press, 1985) 
Beyond the absence of recent conflict, Mongolia offers a positive history of engagement and friendship with the DPRK. This reaches back into the early socialist era, on the one hand, but has been kept an active relationship by democratic Mongolia as well. Frequent reference is made by North Koreans, for example, to the fact that then-Ambassador J Sambuu remained in Pyongyang during the bombing of that city in $1950 .{ }^{11}$ This followed on Mongolia formally recognizing the DPRK as the second country and created the historical basis for on-going friendship during the socialist era. This friendship was carried over into the 1990s and Mongolian policy continued to maintain links with the DPRK through military and other exchanges, mutual visits, and also through food aid.This relationship with the DPRK also allowed Mongolia to hosts dialogue meetings between Japanese and North Korean representatives to discuss the question of Japanese abductees, for example. ${ }^{12}$ In the democratic era, then-Mongolian President Ts Elbegdorj created the Ulaanbaatar Dialogue Initiative on Northeast Asian Security, which has established itself as a regular venue for track 1.5 interactions and could take on a similar role to the Helsinkibased OSCE dialogues during the Cold War.It is in this hosting function that Mongolia might have most to offer to a regionalization process. Put simply, all regional players are reasonably comfortable in Mongolia.

A final contribution that Mongolia might make to regionalization is to serve as an example of different trajectories of transformations. While some of these processes might not seem perfect or to have brought about ideal outcomes, they do offer some experience for any kind of transformation of the DPRK that appears to be a precondition for regional integration. Three transformations are of particular importance in this regard: 1. Regime change, 2. Economic transformation, and 3. An embrace of nuclear-free status.

Mongolia's peaceful revolution hinged on a decision by the Politburo in 1990 not to give orders to repress demonstrations, not to have Mongolian troops open fire on fellow-Mongolians. ${ }^{13}$ This was in stark contrast to the other contemporaneous example of how to respond to political challenges, Tiananmen Square in 1989. But it is not only the moment of challenge that might provide an example to the North Korean regime, but the subsequent fate of the Party. Nearly 30 years after the democratic revolution, the Mongolian People's Revolutionary Party - having dropped the Revolution from its name in 2010 remains a powerful force in Mongolian society and has alternated in dominating

11 Julian Dierkes, "Mongolia's Role in Engaging North Korea", Mongolia Focus, http://blogs. ubc.ca/mongolia/2018/mongolias-role-in-engaging-north-korea/(Accessed on 17 July 2018)

12 See "Talks between Japan and North Korea on the Abductions Issue", 16 December 2015, https://www.mofa.go.jp/a_o/na/kp/page1we 000069.html (Accessed 16 July 2018).

13 Julian Dierkes (eds), Change in Democratic Mongolia: Social Relations, Health, Mobile Pastoralism, and Mining (Leiden, The Netherlands: Brill, 2012), pp. 1-17. 
parliament with the Democratic Party. Unlike many situations in post-socialist Eastern Europe, the Party has not disappeared.

Mongolia's economic transformation also might be of interest to DPRK policy-makers. Not only did Mongolia embrace markets in 1990, but it later on set itself on a course to become a resource-driven economy. Most observers seem to expect that any North Korean economic opening would lead to the DPRK becoming a destination for low-wage manufacturing; the resources that North Korea offers (zinc and iron, for example) may emerge as an additional economic driver making Mongolia's experience relevant.

Finally, while Mongolia was never a nuclear power nor did it have such ambitions, the acceptance of its self-declaration as nuclear-free by the UN Security Council gives it some credibility in hosting discussions of denuclearization and of pointing in a possible direction for the region.

\section{Conclusion}

In scenarios considering an emerging Northeast Asian region, Mongolia would have an opportunity to act on interests in this emergence, but also to contribute to the region-building process. While Mongolia has a strong political and economic interest in the emergence of a Northeast Asian region, it has little to offer to such a process materially. However, depending on the nature of the evolving US-DPRK and ROK-DPRK relationships, Mongolia could have potentially very significant hosting power and thus might emerge as a lynchpin participant in some regionalization trajectories.

Julian Dierkes - a sociologist at the University of British Columbia where he is an associate professor in the School of Public Policy and Global Affairs. Mongolia is most interesting to him for its democratization and mining policy. Mendee Jargalsaikhan - a Political Science PhD candidate at the University of British Columbia. His research focuses on security and democracy of Northeast and Central Asia. 